\title{
MENINGKATKAN HASIL BELAJAR SISWA KELAS IV DI SDN BABAKAN TAROGONG 5 BANDUNG PADA PEMBELAJARAN IPS MELALUI STRATEGI PEMBELAJARAN PEMECAHAN MASALAH
}

\author{
Eros Rosilah \\ SD Negeri Babakan Tarogong 5, Bojongloa Kaler, Bandung, email: rosilaheros7@ gmail.com
}

\begin{abstract}
Learning Social Studies (IPS) is a compulsory subject taught. Learning IPS has a very wide range of material. Reality on the ground results of test scores of fourth grade students of SDN Babakan Tarogong 5 in social studies subject of natural resources, economic activity and technological advances in the district / city and province is still very low. This is due to social studies learning not meet minimum completeness, because the strategy used so far have not matched the learning process. The purpose of this study to determine the activities of students in participating in learning by using learning strategies of problem solving. The results of this research has reached the average value of the class.
\end{abstract}

Keyword : Natural resources, economic activities, technological progress.

\begin{abstract}
ABSTRAK
Pembelajaran Ilmu Pengetahuan Sosial (IPS) merupakan mata pelajaran yang wajib diajarkan. Pembelajaran IPS memiliki cakupan materi yang sangat luas. Kenyataan di lapangan hasil nilai ulangan siswa kelas IV SDN Babakan Tarogong 5 pada mata pelajaran IPS pokok bahasan sumber daya alam, kegiatan ekonomi dan kemajuan teknologi di lingkungan kabupaten/kota dan provinsi masih sangat rendah. Hal ini disebabkan pembelajaran IPS belum memenuhi ketuntasan minimal, karena strategi yang digunakan selama ini belum sesuai dengan proses pembelajaran. Tujuan penelitian ini untuk mengetahui aktivitas siswa dalam mengikuti pembelajaran dengan menggunakan strategi pembelajaran pemecahan masalah. Hasil penelitian ini sudah mencapai nilai rata-rata kelas.
\end{abstract}

Kata kunci : Sumber daya alam, kegiatan ekonomi, kemajuan teknologi.

\section{PENDAHULUAN}

Keberhasilan dalam pembelajaran dipengaruhi oleh faktor-faktor yang terlibat dalam semua kegiatan belajar mengajar. Diantara faktor-faktor tersebut adalah siswa, guru, kebijakan pemerintah dalam membuat kurikulum, serta dalam proses belajar seperti metoda, sarana dan prasarana (media pembelajaran), model, dan pendekatan belajar yang digunakan. Rendahnya mutu pembelajaran dapat diartikan kurang efektifnya proses pembelajaran. Penyebabnya dapat berasal dari siswa, guru maupun sarana dan prasarana yang ada. Belajar adalah suatu perubahan yang terjadi dalam disposisi atau kapabilitas seseorang, dalam kurun waktu tertentu. Melalui proses belajar, anak dapat mengadaptasikan dirinya pada lingkungan hidupnya.

Selain itu, IPS sebagai disiplin ilmu yang memiliki sensitivitas tinggi terhadap dinamika perkembangan masyarakat. Tujuan utama IPS adalah untuk mengembangkan potensi peserta didik agar peka terhadap masalah sosial yang terjadi di masyarakat. Oleh karenanya, guru abad sekarang harus mampu meningkatkan profesionalismenya serta senantiasa beradaptasi dengan dinamika perkembangan dunia pendidikan pada khususnya dan dinamika global pada umumnya.

Hasil belajar yang merupakan daya serap siswa yang berupa kemampuan kognitif atau kemampuan mengerjakan tes sampai sekarang masih menjadi pedoman untuk menaikan siswa ke kelas yang lebih tinggi dan menerima siswa baru. Dalam kenyataan di lapangan sesuai data dalam leger nilai ulangan semester genap kelas IV SDN Babakan Tarogong 5 Bandung diperoleh data bahwa hasil belajar siswa pada mata pelajaran IPS pokok bahasan sumber daya alam, kegiatan ekonomi dan kemajuan teknologi masih sangat rendah atau masih di 
bawah kreteria ketuntasan minimal (KKM). Hal ini disebabkan pembelajaran IPS strategi pembelajaran yang digunakan guru selama ini belum sesuai dengan proses pembelajaran dan materi yang diajarkan.

Permasalahan penelitian ini akan dibatasi dalam beberapa hal saja yang dianggap paling dominan dirasakan selama kegiatan belajar sebelumnya, yaitu sejauh mana upaya strategi pembelajaran pemecahan masalah dalam meningkatkan hasil belajar siswa kelas IV SDN Babakan Tarogong 5 Bandung pada mata pelajaran IPS, pokok bahasan sumber daya alam, kegiatan ekonomi dan kemajuan teknologi di lingkungan kabupaten/kota dan provinsi.

Tujuan yang akan diperoleh dalam penelitian ini adalah : 1) Untuk mengetahui aktivitas siswa kelas IV SDN Babakan Tarogong 5 Bandung dalam mengikuti pembelajaran dengan menggunakan strategi pembelajaran Pemecahan masalah, 2) Untuk mengetahui hasil belajar siswa kelas IV SDN Babakan Tarogong 5 Bandung pada pelajaran IPS pada setiap siklus.

\section{METODE PENELITIAN}

Metode penelitian terhadap hasil belajar siswa kelas IV di SDN Babakan Tarogong 5 Kota Bandung pada pembelajaran IPS adalah dengan menggunakan Penelitian Tindakan Kelas (PTK). Hasil belajar siswa adalah nilai yang diperoleh siswa selama kegiatan belajar mengajar. Belajar diartikan sebagai gejala perubahan tingkah laku yang relatif permanen dari seseorang dalam mencapai tujuan tertentu. (De Cecco, dalam Witjaksono, 1985:6). Menurut Gagne (dalam Witjaksono, 1985:6), belajar adalah suatu perubahan yang terjadi dalam disposisi atau kapabilitas seseorang, dalam kurun waktu tertentu, dan bukan sematamata sebagai proses pertumbuhan. Pendapat senada juga diutarakan oleh Susanto (1991:1) yang menyatakan bahwa belajar merupakan proses dimana otak atau pikiran mengadakan reaksi terhadap kondisi-kondisi luar dan reaksi itu dapat dimodifikasi dengan pengalamanpengalaman yang dialami sebelumnya. Melalui proses belajar anak dapat mengadaptasikan dirinya pada lingkungan hidupnya. Adaptasi itu dapat berupa perubahan pikiran, sikap, dan ketrampilan.
Hasil belajar yang diukur pada pembelajaran yang berlandaskan kurikulum 2004 meliputi kemampuan kognitif, afektif, dan psikomotor. Maka guru tidak hanya menilai siswa dari aspek intelektual tetapi kemampuan sosial, sikap siswa selama proses belajar mengajar serta keaktifan siswa dalam kegiatan pembelajaran juga dinilai oleh guru. Siswa yang telah mengalami pembelajaran diharapkan memilki pengetahuan dan ketrampilan baru serta perbaikan sikap sebagai hasil dari pembelajaran yang telah dialami siswa tersebut. Pengukuran hasil belajar bertujuan untuk mengukur tingkat pemahaman siswa dalam menyerap materi. Sebaiknya hasil belajar yang telah dinilai oleh guru diberitahukan kepada siswa agar siswa mengetahui kemajuan belajar yang telah dilakukannya serta kekurangan yang masih perlu diperbaiki. Penilaian hasil belajar pada akhirnya sebagai bahan refleksi siswa mengenai kegiatan belajarnya dan refleksi guru terhadap kemampuan mengajarnya serta mengevaluasi pencapaian target kurikulum.

Strategi Pemecahan masalah menurut Sudirman, dkk. (1991 : 146) adalah cara penyajian bahan pelajaran dengan menjadikan masalah sebagai titik tolak pembahasan untuk dianalisis dan disintesis dalam usaha mencari pemecahan atau jawabannya oleh siswa. Strategi Pemecahan masalah (Pemecahan masalah) ini sering dinamakan atau disebut juga dengan eksperimen method, reflective thinking method, atau scientific method (Sudirman, dkk., 1991 : 146).

Dengan demikian, strategi Pemecahan masalah (Pemecahan masalah) adalah sebuah strategi pembelajaran yang berupaya membahas permasalahan untuk mencari pemecahan atau jawabannya. Sebagaimana strategi mengajar, strategi Pemecahan masalah sangat baik bagi pembinaan sikap ilmiah pada para siswa. Dengan strategi ini, siswa belajar memecahkan suatu masalah menurut prosedur kerja strategi ilmiah.

Sumber data pada penelitian ini diambil dari pengamatan kepada siswa kelas IV SDN Babakan Tarogong 5 Bandung. Pada saat pembelajaran berlangsung dilakukan observasi terhadap aktivitas siswa oleh observer dengan format observasi yang telah disediakan sebagai salah satu teknik pengumpulan data. Setiap 20 menit sekali pengamat mengamati aktivitas 
siswa, dan menandai aspek aktivitas yang dominan yang dilakukan siswa pada lembar observer, serta memantau jalannya tes evaluasi pada akhir pembelajaran. Pengamatan terhadap aktivitas siswa dilaksanakan sejak dimulainya kegiatan pembelajaran. Analisis data menggunakan pengolahan data secara analisis prosentase deskriptif, yaitu prosentase yang digunakan untuk menganalisis data dengan cara menggambarkan atau mendeskripsikan data yang telah terkumpul sebagaimana adanya.

\section{HASIL DAN PEMBAHASAN}

Pada siklus I, antusias siswa dalam pembelajaran aktivitas dalam mengikuti kegiatan kelompok, aktivitas dalam mendis- kusikan tugas, aktivitas siswa dalam mempresentasikan hasil kegiatan kelompok, dan membuat kesimpulan mengenai pengetahuan yang didapat setelah pembelajaran masih kurang. Bila dilihat secara keseluruhan, aktivitas siswa kelas IV SDN Babakan Tarogong 5 Bandung berada dalam kategori kurang yaitu 48,50\%.

Hasil observasi tingkat pemahaman siswa diperoleh dari nilai hasil tes sebelum dan sesudah dilaksanakan tindakan. Hasil observasi pemahaman siswa dapat di lihat dari meningkatnya nilai rata-rata siswa pada siklus I jika dibandingkan dengan nilai rata-rata siswa sebelum dilaksanakan tindakan, yang akan dideskripsikan pada tabel 1 .

Tabel 1. Data Hasil Observasi Prestasi Hasil Belajar Siswa Siklus I

\begin{tabular}{|c|c|c|c|}
\hline $\mathrm{NO}$ & NAMA & $\begin{array}{c}\text { HASIL BELAJAR } \\
\text { SEBELUM TINDAKAN }\end{array}$ & $\begin{array}{l}\text { HASIL BELAJAR } \\
\text { SIKLUS I }\end{array}$ \\
\hline 1 & Ahmad Yusuf T & 55 & 60 \\
\hline 2 & Akbar Maulana & 60 & 65 \\
\hline 3 & Aldo Lintang S & 55 & 65 \\
\hline 4 & Alif Alfarizi & 50 & 65 \\
\hline 5 & Ananda Resthi P & 50 & 55 \\
\hline 6 & Anggun Meisya & 45 & 55 \\
\hline 7 & Auliana Risnadi & 60 & 65 \\
\hline 8 & Biyandra Vierly & 65 & 70 \\
\hline 9 & Dina Naifah & 55 & 65 \\
\hline 10 & Ervina Ardelia & 50 & 65 \\
\hline 11 & Fahimah Rodiah & 55 & 70 \\
\hline 12 & Ghazi Hasya & 65 & 70 \\
\hline 13 & Gilang Ramadhan & 65 & 75 \\
\hline 14 & Hilyah Fariha M & 70 & 75 \\
\hline 15 & Kristina Sopandi & 45 & 55 \\
\hline 16 & Lolana Naila & 50 & 60 \\
\hline 17 & Luthfi Satria & 55 & 65 \\
\hline 18 & M. Albi Fakhul F & 60 & 65 \\
\hline 19 & M. Dzaky Nugraha & 60 & 70 \\
\hline 20 & Melda Umar D & 55 & 60 \\
\hline 21 & Nabil Mudzaky & 55 & 60 \\
\hline 22 & Nazla Salsabila & 60 & 65 \\
\hline 23 & Nesta Aurellia & 55 & 65 \\
\hline 24 & Putri Kurniawati & 50 & 65 \\
\hline 25 & Rahi Mahesa & 50 & 55 \\
\hline 26 & Raisya Athalia & 45 & 55 \\
\hline 27 & Raisya Syahidah & 60 & 65 \\
\hline 28 & Rayna Rindu P & 65 & 70 \\
\hline 29 & Rehan Noviana & 55 & 65 \\
\hline 30 & Reska Perdiana & 50 & 65 \\
\hline
\end{tabular}




\begin{tabular}{llcc}
\hline 31 & Ridho Ramadhan & 55 & 70 \\
\hline 32 & Rizky Dwi S & 65 & 70 \\
\hline 33 & Silvi Nur Fadillah & 65 & 75 \\
\hline 34 & Syahru Fakhurozi & 70 & 75 \\
\hline 35 & Taufik Rahman & 45 & 55 \\
\hline 36 & Tony Radita & 50 & 60 \\
\hline Jumlah & 2020 & 2330 \\
\hline Rata-rata & 56,11 & 64,72 \\
\hline
\end{tabular}

Hasil observasi peningkatan hasil belajar siswa di atas dapat di lihat bahwa pembelajaran dengan strategi pembelajaran Pemecahan masalah dapat meningkatkan hasil belajar siswa dari yang sebelum menggunakan strategi pembelajaran pemecahan masalah nilai ratarata siswa dalam pembelajaran IPS sebesar 56,11 menjadi 64,72 pada tindakan siklus 1 .

Sedangkan pada siklus II, antusias siswa dalam pembelajaran aktivitas dalam mengikuti kegiatan kelompok, aktivitas dalam mendiskusikan tugas, aktivitas siswa dalam mempresentasikan hasil kegiatan kelompok, dan membuat kesimpulan mengenai pengetahuan yang didapat setelah pembelajaran memiliki kategori baik. Bila dilihat secara keseluruhan, aktivitas siswa kelas IV SDN Babakan Tarogong 5 Bandung berada dalam kategori baik yaitu $71,00 \%$. Artinya aktivitas siswa pada siklus II ini mengalami peningkatan dibandingkan dengan aktivitas siswa pada siklus II.

Hasil observasi tingkat pemahaman siswa siswa diperoleh dari nilai hasil tes sebelum dan sesudah dilaksanakan tindakan. Hasil observasi pemahaman siswa dapat di lihat dari meningkatnya nilai rata-rata siswa pada siklus II jika dibandingkan dengan nilai rata-rata siswa sebelum dilaksanakan tindakan, yang akan dideskripsikan pada tabel 2 .

Tabel 2. Data Hasil Observasi Prestasi Hasil Belajar Siswa Siklus II

\begin{tabular}{llcc}
\hline NO & \multicolumn{1}{c}{ NAMA } & $\begin{array}{c}\text { HASIL BELAJAR } \\
\text { SEBELUM TINDAKAN }\end{array}$ & $\begin{array}{c}\text { HASIL BELAJAR } \\
\text { SIKLUS II }\end{array}$ \\
\hline 1 & Ahmad Yusuf T & 55 & 70 \\
\hline 2 & Akbar Maulana & 60 & 75 \\
\hline 3 & Aldo Lintang S & 55 & 75 \\
\hline 4 & Alif Alfarizi & 50 & 75 \\
\hline 5 & Ananda Resthi P & 50 & 65 \\
\hline 6 & Anggun Meisya & 45 & 60 \\
\hline 7 & Auliana Risnadi & 60 & 70 \\
\hline 8 & Biyandra Vierly & 65 & 75 \\
\hline 9 & Dina Naifah & 55 & 75 \\
\hline 10 & Ervina Ardelia & 50 & 75 \\
\hline 11 & Fahimah Rodiah & 55 & 80 \\
\hline 12 & Ghazi Hasya & 65 & 80 \\
\hline 13 & Gilang Ramadhan & 65 & 80 \\
\hline 14 & Hilyah Fariha M & 70 & 65 \\
\hline 15 & Kristina Sopandi & 45 & 70 \\
\hline 16 & Lolana Naila & 50 & 70 \\
\hline 17 & Luthfi Satria & 55 & 70 \\
\hline 18 & M. Albi Fakhul F & 60 & 75 \\
\hline 19 & M. Dzaky Nugraha & 60 & 70 \\
\hline 20 & Melda Umar D & 55 & 75 \\
\hline 21 & Nabil Mudzaky & 55 & 60 \\
\hline 22 & Nazla Salsabila & & 70 \\
\hline & & 60 & \\
\hline
\end{tabular}




\begin{tabular}{llcc}
\hline 23 & Nesta Aurellia & 55 & 75 \\
\hline 24 & Putri Kurniawati & 50 & 75 \\
\hline 25 & Rahi Mahesa & 50 & 65 \\
\hline 26 & Raisya Athalia & 45 & 60 \\
\hline 27 & Raisya Syahidah & 60 & 70 \\
\hline 28 & Rayna Rindu P & 65 & 75 \\
\hline 29 & Rehan Noviana & 55 & 75 \\
\hline 30 & Reska Perdiana & 50 & 75 \\
\hline 31 & Ridho Ramadhan & 55 & 80 \\
\hline 32 & Rizky Dwi S & 65 & 80 \\
\hline 33 & Silvi Nur Fadillah & 65 & 80 \\
\hline 34 & Syahru Fakhurozi & 70 & 80 \\
\hline 35 & Taufik Rahman & 45 & 65 \\
\hline 36 & Tony Radita & 50 & 70 \\
\hline Jumlah & 2020 & 2625 \\
\hline Rata-rata & 56,11 & 72,91 \\
\hline
\end{tabular}

Dari perolehan hasil observasi peningkatan hasil belajar siswa di atas dapat di lihat bahwa pembelajaran dengan strategi pembelajaran Pemecahan masalah dapat meningkatkan hasil belajar siswa dari yang sebelum menggunakan strategi pembelajaran Pemecahan masalah nilai rata-rata siswa dalam pembelajaran IPS sebesar 56,11 menjadi 72,91 pada tindakan siklus II.

Pembelajaran IPS pada pokok bahasan sumber daya alam, kegiatan ekonomi dan kemajuan teknologi di lingkungan kabupaten/kota dan provinsi dengan menggunakan strategi pemecahan masalah merupakan hal yang baru bagi siswa kelas IV SDN Babakan Tarogong 5 Bandung, tetapi siswa cukup antusias dan terlihat senang dalam mengikuti pembelajaran tersebut. Dapat dilihat dari prosentase siswa yang menyatakan senang dengan penggunaan strategi Pemecahan masalah sebesar $78,4 \%$, dan hanya $21,6 \%$ siswa yang menyatakan kurang senang.

Mengenai aktivitas siswa selama pembelajaran, dapat dikemukakan bahwa pembelajaran IPS pokok bahasan Sumber daya alam, kegiatan ekonomi dan kemajuan teknologi di lingkungan kabupaten/kota dan provinsi dengan menggunakan strategi Pemecahan masalah dapat meningkatkan aktivitas siswa, dapat menciptakan kondisi sehingga siswa dapat berperan aktif dan mengurangi kecenderungan pembelajaran yang berpusat pada guru (teacher centered). Hal ini dapat dilihat dari hasil observsi mengenai aktivitas siswa pada siklus I sebesar 48,50 dan meningkat pada siklus II menjadi 71,00.

Peningkatan hasil belajar siswa pada pembelajaran IPS dengan strategi pembelajaran pemecahan masalah dapat meningkatkan hasil belajar siswa dari yang sebelum menggunakan strategi pembelajaran pemecahan masalah nilai rata-rata siswa dalam pembelajaran IPS sebesar 56,11 menjadi 64,72 pada tindakan siklus 1 dan 72,91 pada tindakan siklus 2. Artinya, pada pembelajaran siklus 2 hasil belajar siswa meningkat dan mencapai standar KKM yang telah ditentukan (70) dan mencapai tingkat pemahaman yang baik terhadap materi yang disampaikan dengan gain sebesar 12,86.

Pada siklus 1 perolehan rata-rata kelas sebesar 64,72 sehingga termasuk dalam kategori cukup dan belum bisa dikatakan sebagai nilai baik, sedangkan daya serap siswa sebesar 21,94\% dan ketuntasan belajar secara kelompok sebesar $30,55 \%$ atau 11 siswa dikatakan tuntas dari jumlah keseluruhan 36 orang siswa. Artinya penelitian tindakan kelas pada siklus 1 dianggap belum berhasil karena rata-rata nilai hanya mencapai angka 64,72 kurang dari nilai KKM yang ditentukan yaitu 70. Sedangkan pada siklus 2 perolehan rata-rata kelas sebesar 72,91 sehingga termasuk dalam kategori nilai baik, sedangkan daya serap siswa sebesar 62,36\% dan ketuntasan belajar secara kelompok sebesar $83,33 \%$ atau 30 orang siswa dikatakan tuntas dari jumlah keseluruhan 36 orang siswa. Artinya penelitian tindakan kelas pada siklus 2 dianggap telah berhasil karena 
rata-rata nilai telah mencapai angka $72,91 \%$ melebihi dari nilai KKM yang ditentukan yaitu 70 .

\section{PENUTUP}

Hasil prosentase pembelajaran Ilmu Pengetahuan Sosial pokok bahasan sumber daya alam, kegiatan ekonomi dan kemajuan teknologi di lingkungan kabupaten/kota dan provinsi dengan menggunakan strategi pemecahan masalah menyatakan siswa senang dengan penggunaan strategi pemecahan masalah sebesar $78,4 \%$, dan hanya $21,6 \%$ siswa yang menyatakan kurang senang.

Penggunakan strategi pemecahan masalah juga dapat meningkatkan aktivitas siswa, dapat menciptakan kondisi sehingga siswa dapat berperan aktif dan mengurangi kecenderungan pembelajaran yang berpusat pada guru (teacher centered). Hal ini dapat dilihat dari hasil observsi mengenai aktivitas siswa pada siklus 1 sebesar 48,50 dan meningkat pada siklus 2 menjadi 71,00 .

Strategi pembelajaran pemecahan masalah juga dapat meningkatkan hasil belajar siswa dari yang sebelum menggunakan strategi pembelajaran pemecahan masalah nilai ratarata siswa dalam pembelajaran IPS sebesar 56,11 menjadi 64,72 pada tindakan siklus 1 dan 72,91 pada tindakan siklus 2. Artinya, pada pembelajaran siklus 2 hasil belajar siswa meningkat dan mencapai standar KKM yang telah ditentukan (70) dan mencapai tingkat pemahaman yang baik terhadap materi yang disampaikan dengan gain sebesar 12,86.

Pada siklus 1 perolehan rata-rata kelas sebesar 64,72 sehingga termasuk dalam kategori cukup dan belum bisa dikatakan sebagai nilai baik, sedangkan daya serap siswa sebesar 21,94\% dan ketuntasan belajar secara kelompok sebesar $\mathbf{3 0 , 5 5 \%}$ atau 11 siswa dikatakan tuntas dari jumlah keseluruhan 36 orang siswa. Artinya penelitian tindakan kelas pada siklus 1 dianggap belum berhasil karena rata-rata nilai hanya mencapai angka 64,72 kurang dari nilai KKM yang ditentukan yaitu 70. Sedangkan pada siklus 2 perolehan rata-rata kelas sebesar 72,91 sehingga termasuk dalam kategori nilai baik, sedangkan daya serap siswa sebesar $62,36 \%$ dan ketuntasan belajar secara kelompok sebesar $83,33 \%$ atau 30 orang siswa dikatakan tuntas dari jumlah keseluruhan 36 orang siswa. Artinya penelitian tindakan kelas pada siklus 2 dianggap telah berhasil karena rata-rata nilai telah mencapai angka $72,91 \%$ melebihi dari nilai KKM yang ditentukan yaitu 70 .

\section{DAFTAR PUSTAKA}

Arifin, Zaenal. (1988). Evaluasi Instruksional Prinsip dan Teknik Prosedur, Bandung : Remaja Karya.

Daradjat, Zakiah. (2004). Metodik Khusus Agama Islam, Jakarta : Bumi Aksara.

Departemen Pendidikan Nasional, (2004). Kegiatan Belajar Mengajar. Jakarta: DEPDIKNAS.

Hasbullah, (2001). Filsafat Pendidikan, Bandung: Alfabeta.

Kasihani, dkk, (1998), Metode Penelitian Tindakan Kelas, Jakarta: Rineka Cipta.

Koswara, Engkos. (1988). Dasar-dasar Metodologi Pengajaran, Jakarta : Bumi Aksara.

Makmun, Abin Syamsudin, (1992). Psikologi Pendidikan, Bandung: IKIP.

Mulyasa, E. (2014). Menjadi Guru Profesional Menciptakan Pembelajaran Kreatif dan Menyenangkan. Bandung: Remaja Rosda Karya.

Nasution, S. (1982). Berbagai Pendekatan dalam Proses Belajar Mengajar. Jakarta: PT Bina Aksara.

Poerwadaminta, WJS. (1989). Kamus Umum Matematika, Jakarta: Depdikbud.

Purwanto, Ngalim, (1995). Ilmu Pendidikan Teoritis dan Praktis. Bandung: Remaja Rosdakarya.

Slameto, (2003). Belajar dan Faktor-faktor yang mempengaruhinya. Jakarta: Rineka Cipta.

Sodikin, E. (2000). Penelitian Tindakan Kelas, Bandung: Rizqi Press.

Sudjana, Nana, (1990), Dasar-dasar Proses Belajar Mengajar, Bandung: PT Sinar Baru Algesindo.

Tu'u, Tulus, (2004). Peran Disiplin Prilaku dan Prestasi Siswa, Jakarta: Grasindo.

Virlianti, A. (2003), Pengantar Psikologi Pendidikan, Bogor: Ghalia.

Wiriaatmadja, R. (2014). Metode Penelitian Tindakan Kelas. Bandung: Rosdakarya. 